\title{
Domestic Tourists Perception Towards the Object Quality and Fascination of Manikin Beach in Kupang Regency
}

\author{
Christina Mariana Mantolas*, Yudha Eka Nugraha, Martarida Bagaihing \\ Tourism Department \\ Politeknik Negeri Kupang \\ Kupang, Indonesia \\ *christina.mantolas@pnk.ac.id, yudhaekanugraha@gmail.com, eedatha@gmail.com
}

\begin{abstract}
This study aims to find out the perception of domestic tourists on the fascination of Manikin Beach in Kupang regency. The total number of respondents who involve in this study are 100 respondents, the technique of sampling is using non probability sampling. The respondents are 38 males and 62 females. Mostly they are staying in Kupang. This quantitative study is using survey over tourists and spreading questionnaires. Data analysis of this study is using Likert scale technique, commonly used to measure behaviour, opinion, and perception. The result of this study shows that the tourist perception on Manikin Beach's quality and fascination in Kupang regency is poor based on its attraction, accommodation, accessibility, the government is still giving less attention to building supporting facilities, and the society who are living around Manikin beach are less aware with the business opportunity in tourism and also the lack of society involvement in taking care, maintaining, and cleaning of Manikin Beach and its surroundings.
\end{abstract}

Keywords—perception, tourists, object quality, fascination

\section{INTRODUCTION}

In the last 5 years, the overall development of tourism in East Nusa Tenggara (NTT) is increasing. It can be seen from the total number of visitors that always increasing with more than $15 \%$ of growth every year. This trend is well perceived by the current Governor of NTT as an opportunity to develop and to put the tourism sector as one of the top priorities in NTT. In addition, Timor island as one of the regions in NTT has a lot of attractive destinations for tourists and this should be taken into considerations.

A There are a lot of beautiful beaches in Timor island favoured by both domestic and international tourists and most of these sites have been managed by either the communities, or the government. One of these touristic sites is Manikin Beach. Its strategic location that lies between the administrative region of Kupang City and the district of Kupang and its marine potential make this site as a favourable site for most of the people in these two regions. However, this opportunity has not been supported well and it can be seen from the lack of facilities provided on this site [1].

As a result, this affects the fluctuate number of visitors in this site. If only the management and the maintenance of facilities especially on the $4 A$ dimensions (Attractions, Amenity, Accessibility, Ancillary) have been taken care of well, this will boost the number of visitors and the economic potentials both for the government and the community. The objective of this research is aiming to understand the perception of domestic tourists toward the marine tourismpotentials in Manikin beach. It is expected that after understanding this perception, the results can be used as an evaluation for those who manage this site, this potential can be maximized in the future that can fulfil the needs of the tourists in a more sustainable way.

It is undeniable that the main factors of many touristic sites are about its natural attractions that can be enjoyed by the tourists who come to the site. Manikin Beach does not only offer its own unique attraction but also its strategic location that that can be enjoyed by both people in the district of Kupang and City of Kupang. It is located in Tarus village, District of Kupang. The availability of access to this place made it easier for people to come and visit as it only $13 \mathrm{Km}$ away from the centre of Kupang City. Not only that, along the way to the site, the visitors will also enjoy a beautiful scenery of rice field as this village has the privilege of having abundance resource of water that encourages its people to cultivate their lands. Not to mention, its perfect sunset that will always captivate the eyes of the beholder.

The unique view of the ocean and waves are easily accessible by the visitors and they will be able to enjoy these attractions from the edge of the shore which then sometimes encouraged the visitors to stay longer as they enjoy these attractions. This aligns with the definition stated by government in the UU Number 10 in 2009 about tourism that explained that a touristic attraction should have its own 
uniqueness, beauty and value that can be enjoyed by the tourists themselves.

Manikin beach is also one of the tourism destinations sites or DTW. According to Leiper [2] the tourist will visit either 3 of these geographical sites: Original Touristic Region or Daerah Asal Wisata (DAW), Touristic-destination Region or Daerah Tujuan Wisata (DTW), and transit region or Daerah Transit (DT). DTW is a region that is visited by the visitors for the intention to do leisure activities as it has its touristic attractions and this area can also be the main driver of the overall tourism system in the region. In this case, the Manikin beach has also an increasing number of the visitors.

In order to have the figures of the visitors in this site, in the last 6 years the number can be obtained from the Tourism Department and Creative Economy Office in the District of Kupang. In 2014, the total number of international visitors in this site was 1175 people while the domestic ones were 6935 people totally overall visitors in that year to be at 8110 visitors. In 2015, there were no any international visitors but there were 4100 domestic tourists visiting this site. Back in 2016, there was no international tourists either but there were 4545 domestic visitors on that year. On the other hand, in 2017 there was an increasing of 52 international visitors and 4338 domestic ones (4390 visitors in total) while in 2018 , there were 32 international visitors and 4338 domestic tourists visiting this site with a total of 4390 visitors on that year. Lastly, in 2019 there were 41 international tourists and 3659 domestic visitors that visited that sites with a total of 3700 visitors in that site on that year.

According to that figures we can clearly see that the total number of visitors were declining since the $3^{\text {rd }}$ year. It is suspected that this declining numbers somehow gave a negative response toward the image of the DTW that is unable to satisfy the visitors through its tourism activities. It is also suspected that the District of Kupang did not really prioritize Manikin beach as a top tourism destination for its region. This can be clearly seen through the fact that there are many abandoned facilities in this site such as the public restroom or the shelter on the shore. Not only that, the lack of understanding from the community to preserve this natural attraction and the lack of supporting attractions and business available nearby this site and the lack of support from local government made it worse for Manikin beach to survive as one of the top touristic attractions in this DTW of Kupang District. The lack of funding and un-optimized managerial involves in preserving this site has a direct effect on the declining number of visitors in this beach. This condition is surely made worse the perception of the visitors as well as the image of the tourism product which is in this case Manikin beach itself [3].

According to the aforementioned arguments and facts elaborated above, in order to preserve the quality of the DTW of Manikin beach by the local government especially the Deputy of Tourism in this district, it is important to evaluate this situation by using the 4A dimensions so that we can fully understand the perception of the visitors there (attraction, accessibility, amenities, ancillary). It is expected that through this paper, we can all fully understand the perception of the visitors and improve them in the context of the marine attraction of Manikin beach.

\section{REVIEW OF LITERATURE}

\section{A. Tourists' Perception}

Perception is a process in how an individual decide, organize, interpret the inputs of information to create meaning. Perception is not only depending on physical stimuli, but it also depends on stimuli that relates to surroundings and individual's conditions [4].

There are a few requirements for a perception to take place [5] such as, a) There should be object/objects on which the perception is focused on, b) There should be senses receptor for receiving the stimuli c) There should be attention as an initial reaction in making the perception d) Perception is sometimes interchangeably associated with opinion, behaviour and judgment. Perception is defined as a process that involves nervous system (the brain). So that the individual fully realizes what one sees and what one hears. Thus, it is always important to note that perception always takes place when one receives the stimuli [6]. The perception of the tourist is the judgment of the visitors about something. A tourism site needs to enhance its quality in order to receive a positive perception. Perception in tourism is the way the visitors see and make a judgment about the tourism sites. In tourism industry, every tourist has their own values and personalities that differs one's perception to another.

The perception of the tourist is an important dimension in developing a tourism site. What the tourists want to experience, to expect and to enjoy from the tourism sites are so important especially when it comes to marketing of the tourism sites [7].

\section{B. The Quality of the Tourism Site}

Beside the dimension of the demand from the visitors, we also need to pay attention to the tourism site as a supply dimension. A tourism site is basically a place or geographical area in an administrative region that has potential attractions, facilities, and good accessibility as well as local community to run the tourism activities including the management and the procedural and regulatory sides of it. Tourism destination is basically the interaction from many related elements in tourism that work together well. Those elements are tourists, the tourism sites and the information about the sites as well as the attraction of the sites itself. This is what the system of tourism [8].

Model of functional components that create some kind of dynamics and interaction of tourism system. In general, in a tourism object, there are some sub elements that support each other and has the connection to one another so they can create the unity of tourism site that has values and attractions toward the tourists These sub elements can be categorized in 3 different groups: 1) Attraction: anything that attract the visitors 
to come and visit the tourism sites. 2) The availability of the facilities: all the things that support the tourism sites so that it can be fully enjoyed by the tourists. 3) Accessibility: all the things including the transportation or infrastructure that help the tourists to reach the sites.

Furthermore, the enhancing of the quality of the tourism site is mainly the responsibility of the local government as an effort to diversifying the kinds of tourism [9]. This effort of enhancing the quality of the Lubuk Linggau tourism site is done by giving some additional funding for the maintenance and developing better facilities by taking into considerations the total number of the visitors [10]. This is done so that it can attract more domestic and international tourists. This effort takes a lot of funding so basically it needs a large-scale assessment in order to improve the quality of this site.

In order to improve the number of visiting tourists, it takes an effective method in this Lubuk Linggau site. In order for this effort align with its original objective, it needs a support system to help the decision makers decide what dimension and sectors to improve and putting a priority scale is important in this case. Since we know that the perception of the tourists toward tourism site is really important and a key factor determining them to come and visit again the site, it is important to make a research study about this especially by taking into account these three different sectors of attraction, amenities and accommodation.

Based on the elaboration and facts stated before, below is formulated the thinking scheme of how all parties involve can take part in improving the attractions quality of Manikin beach:

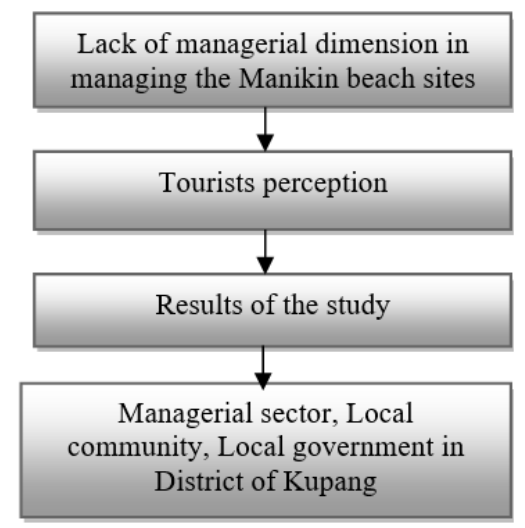

Fig. 1. Thinking scheme of the research study.

\section{METHODS}

This study is a quantitative study by using survey to collect quantitative data. This survey research also use questionnaire to collect data from the determined sample from the population of the tourists that visited Manikin beach. The population in this study is all the visiting tourists in this site. The sampling technique is going to use non-probability sampling with a sample of 100 people.

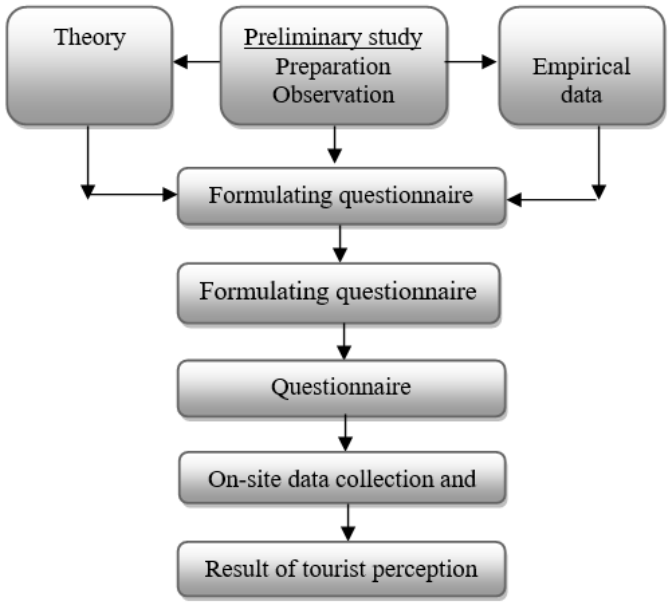

Fig. 2. Research procedure diagram.

\section{A. Location and Research Duration}

This research is conducted in the Manikin beach site as one of the tourism sites in the District of Kupang. Besides, this study is going to be done at certain spots nearby this Manikin beach in order to do further observation in enhancing the quality of the study. This study is going to be conducted to the point that all the things are satisfied and there will be no more changes taking place. The research will be done from July November 2020 and the sample is going to be taken on the Manikin beach site. Aside from the quantitative data, some interviews will also be conducted towards the visitors by disclosing the identity of the interviewer and the objective of the interview

\section{B. Research Subject}

The research subject of this study are the respondents that can inform some information and data about some items asked. These respondents will be 100 visitors in Manikin beach.

\section{Research Instruments.}

The instruments of this quantities study will be in the form of survey and questionnaire. This method is considered proper to use because every respondent will have the same chance. The advantages of using this method instruments are they are effective and efficient in collecting the data. The questionnaire will be in Bahasa Indonesia as the main respondents will be mostly domestics tourists. The question made will be some combinations sets of questions to prompt some responses for gaining the data. The questions will be in a semi-open question to enable every visitor to give different answers and responses.

\section{Data Analysis Techniques}

The data analysis techniques used in this study is going to use Likert scale. Likert scale is commonly used to measure behaviour, opinions and perception of someone or a group of people [11]. The variables measured will be operated into indicator of variable. Furthermore, these indicators will be used 
as an initial step to develop the instruments in the form of sets of questions. The responses for each question will be scaled from very positive to very negative response, This Likert scale can also be formulated in the form of checklist or multiple choices.

\section{RESUlT AND DisCUSSION}

Characteristics of respondents in data collection include gender, age, occupation, origin of domicile, level of education, number of visits, and motivation to visit tourist destinations in Manikin Beach. This is expected to provide a fairly clear picture of the condition of the respondent and its relation to the problem and the research objectives. Respondents base on gender who most visited Manikin beach tourism were women, namely 61 people and 39 men, while the age of the respondents in the study who visited the most coastal locations were 20-29 years old, whereas seen from the work that visited the most to enjoy the object of the tourist destination of Manikin beach are students.

For domicile origin 76 visitors came from Kupang City and 24 people from Kupang Regency. The most recent high school / vocational school education was mostly by visiting respondents, while the motivation for tourist visits was more to choose Manikin beach as a tourist destination because they wanted to enjoy the beauty of the unspoiled beach, and the calm atmosphere around the beach, they also took part with their families to recreation in eliminating boredom and boredom while busy with daily routine tasks and work, seeing the waves and beautiful sunsets, some people around Manikin beach looking for shells, looking for fish by removing the trawl is their routine. In this study, it is proven that the dominant age of the respondents is the productive age. In fact, it does not appear that elderly groups are increasingly involved in tourism activities. The people motives doing tourism activities have been widely studied in sharing studies [12]. In general, it can be concluded that psychological and socio-anthropological motives play a strong role. Psychological motives are related to what psychologist Abraham Maslow formulated as the fulfilment of various human needs. Two of these needs that are closely related to travel motivation are the need for selfactualization and social recognition. Furthermore, the relationship between human needs and motives in the context of tourism, starting from the needs of psychologists, a sense of security, a sense of belonging, self-esteem, self-actualization, expansion of knowledge and aesthetics. Psychologists need to encourage people to do relaxation. Aesthetic needs ultimately encourage someone to appreciate the beauty of nature. These needs and motives can be accommodated through tourism activities. Traveling to restore health can be interpreted as a way to fulfil one's sense of security

Of course the motive for this trip is not uniform in all societies. In the analysis of the social sciences, every social action and behaviour, including in this case conducting tourism activities, is very much related to its background or social, demographic or economic characteristics. In this study, this approach was also carried out with the hope that social phenomena and facts in the form of tourist perceptions of the quality of the ODTW of Manikin Beach could be understood from the perspective of the tourists themselves. Perceptions about the quality of objects and tourist attractions. The low quality of tourist destination objects (not good) will have a negative impact on the perceptions of tourists, resulting in a decrease in the number of visits to Manicin beach attractions, because tourist perceptions become the benchmark for seeing the quality level of the tourist destination objects. Here, the quality of the object of the tourist destination includes uniqueness, authenticity, friendliness, beauty, security, and cleanliness.

Apart from the concern of observers who see this area as being threatened with losing its attractiveness due to the lack of uniqueness of the tourism objects offered (Damanik, 2000), it is proven by the results of respondents' answers regarding perceptions. Respondents or tourists also have low perceptions regarding the shape and authenticity of the building architecture. The friendliness of the community in the location of the tourist destination object of the Manikin beach as the host is important in tourism, because it will affect the satisfaction felt by these tourists. In the context of the service industry, friendly attitude is an important element of the product even though it is intangible. Every tourist who visits tourist destination objects really expects good service. The attractions in Manikin Beach are clearly visible with their natural beauty because they attract the attention of many tourists. This is not much different from the results of the study, where more than 80 percent of respondents gave a very high (very good) perception of the natural beauty of Manikin Beach. These results prove that natural beauty is still one of the biggest draws for tourists, especially domestic tourists.

The last element the respondents perceive is cleanliness. The results of a tourist market study conducted in Europe show that to find tourist destinations that offer cleanliness is an option for some tourists. The final respondents gave a perception of the quality of cleanliness of the object of the tourist destination as much as 65 percent. This result is a positive perception because it is still relatively high (good) in terms of cleanliness. This statement is also supported by sources regarding comments from tourists who have visited and enjoyed Manikin Beach attractions. At the local level, we also see some input regarding supporting facilities such as toilets or lopos which are still found lack in terms of cleanliness, presumably this is good to be considered as the person in charge or manager so that it is necessary to improve and maintain cleanliness around Manikin Beach. The conclusion that can be drawn in general is that for respondents the quality of objects and tourist attractions is classified as average, the perception is still good, with a note that the element of cleanliness is perceived as an element that needs attention, namely still limited facilities in the form of toilets or bathrooms and lopos that are less clean. Even categorized as damaged or unfit for use. Lack of innovation in offering snacks or tourist products that can be offered to tourists in locations around the Manikin Beach. So that it can give an impression when leaving the tourist attraction. 
The following will describe the respondent's perception of the quality of the elements of the Manikin Beach tourist object. As previously explained, from the product side, there are several main components, namely attractions, accommodation and accessibility

\section{A. Perception of Tourist Attraction Quality}

The tourist attractions consist of elements based on the completeness of a tourist attractions consisting of nature presented by the National Park, natural scenery and beaches and lakes. Looking at the components of the attraction here is still very limited, namely only visible activities, looking for shells, tourists whose main purpose is to swim, some tourists only enjoy the beauty of the beach with fresh air and accompanied by the wind, and no less tourists who visit just want to enjoy the sunset on when the sunset, this location is also an alternative option for tourists to do pre-wedding photos.



Fig. 3. Manikin beach is used for pre-wedding photos (Source factapers.id).

Attractions are the major determinants for tourists in selecting a destination, which are also known as the pull travel motives of the tourists. Tourists like to get maximum experience and satisfaction through exploring and enjoying such attractions.

Results highlight that the quality of the attractions has a positive influence on tourists' perception, which would lead them towards higher satisfaction levels. However, it is necessary to provide the adequate infrastructures and other facilities within and outside of the attractions. Furthermore, there should be viable programs to preserve and maintain the quality of attractions, customer education and interpretation programs for tourists' sites and community awareness programs to communicate the importance and benefits of tourism and to take preventive measures to overcome the negative impacts, etc. Highly satisfied and loyal tourists create positive Word of Mouth publicity (WOM) and it is the most powerful influence for the purchasing decision of the potential tourists. It costs four to six times to attract new customer than to retain the existing customers [13]. A satisfied tourist will talk favourably about their satisfaction related to a holiday destination or a hotel, which will spread the positive publicity. A satisfied tourist will tell five others about their positive experiences, while a dissatisfied tourist will tell ten or more others about their negative experiences [14].

\section{B. Quality of Tourist Accommodation}

Accommodation in tourism is known as the second home of the tourists and researchers have identified that many facilities and services affect the hotel selection and tourists' satisfaction. For example, cleanliness and hygiene of the hotel \& rooms [15], conformability, spacious, ventilated and proper maintained rooms [16], and proper room facilities and services i.e. well-equipped and safety features of the bathrooms, proper and better lighting, proper door locks with safety, clean bed linen and mattresses [17] entertainment, sports \& recreational facilities [18] identified the efficient front desk, friendly \& communicative [19], pleasant staff, prompt \& courteous service, congeniality of information counter, and language proficiency of staff affect the tourist satisfaction. This research measures and identifies the tourists' perception and satisfaction regarding the accommodation facilities, room services \& maintenance, quality and standards of bathrooms, night life \& entertainments, shopping facilities, sport \& recreation facilities. Accommodation is one of the tourism products and is an element that determines the quality of the object of the tourist destination as a whole. In this study, the accommodation aspects discussed from the tourist perspective are hotels, entertainment or sports facilities. Judging by respondents perceptions, the quality of accommodation owned by the tourist destination object of Manikin Beach is still low (reality does not yet exist). For managers who are responsible, this needs to be seen as a signal against the threat of weakening the tourist attraction of the area, especially for tourists who have the main goal of staying longer at a location near Manikin Beach. The unavailability of souvenirs typical of Manikin Beach tourist destination objects to be marketed such as carving crafts, plaits, local woven fabrics, typical clothes, wallets or other kinds.

\section{Perceptions of Accessibility Quality}

Accessibility is an important component of tourism products. Accessibility enables tourists to reach the attractions and accommodation offered in the tourist market, and also allows tourists to visit various ODTWs easily and comfortably. The convenience factor in the sense of efficiency and comfort is an inseparable part of this accessibility element. Therefore, the quality of accessibility will determine the attractiveness of a tourist attraction. To see the quality of tourism accessibility, the main indicators are used, namely the quality of tour buses or other means of transportation and roads. Roads are the lifeblood of transportation and the core of tourism accessibility. Especially in tourist destinations whose tourism products are based on land topography, the role of roads cannot be completely ignored.

The Kupang district government plays an important role because this destination is one of the tourist destinations that have a large proportion of the distribution of ODTW in urban boundary areas, so roads play an important role in providing access to tourists.

Most of the respondents' views said that the quality of the roads was poor. Because some of the roads are damaged and 
narrow, but still in a beautiful view because the access road to the ODTW location is still natural and fresh to the eye because tourists can enjoy the cool air, fresh breeze and views of green rice fields and can also enjoy a beautiful sunset. Although this explanation as a whole the percentage of respondents who perceive the quality of accessibility is quite significant, the magnitude is not absolutely prominent. Compared to the quality of other ODTW components, in general, respondents rated the quality of tourism accessibility to be lower. This view needs to be studied further by looking at the various variables that might influence it.

\section{CONCLUSION}

Judging from the respondent characteristics of the productive age, the education of students, they hope for the future of attention and support in the development of tourist destinations for Manikin Beach. In general, the quality of the tourist attraction object of the Manikin beach is well perceived. This means that by using standard parameters, it turns out that for most domestic tourists, the quality of some elementary elements in tourist destination objects is perceived as having good quality to provide tourism satisfaction. Nonetheless, there were elements of a tourist product whose quality was brought up to the standards of their belief that this tourist attraction will provide optimal tourism satisfaction. If you look at their generally good perceptions of the tourist destination objects, it seems that these expectations are fulfilled. desires. The expectations given by domestic tourists on Manikin beach attractions are quite high.

The representation of the fulfilment of these expectations is without the level of satisfaction experienced by most of these tourists. Related to this, it is clear that the functional linkages and parallels between high expectations and good perceptions and with optimal tourism satisfaction. The findings in this study can provide empirical evidence that from a tourist perspective, the quality of tourist objects in Manikin Beach is still relatively good all tourism stakeholders are expected to be able to anticipate and respond earlier to trends in changes that occur or are experienced in tourist destination objects. As one example, their relevant perceptions of tourist destination objects not only need to be maintained but also pay attention to planning the preparation of quality standards for tourism products (attractions, accessibility and accommodation) based on the criteria of uniqueness, authenticity, beauty, safety, comfort, memories, hospitality and cleanliness and may well be applied.

This research is a finding that can provide new challenges for tourism stakeholders in this case the Manikin Beach community, managers and people in charge, namely the
Kupang Regency Tourism Office to improve performance, can also give new colours meaning to create innovation in the development of tourism products in the future. So that it can meet new demands or the quality of tourism services that are expected to increase for the advancement of the tourist destination of Manikin Beach.

\section{REFERENCES}

[1] A.H. Karyono, Tourism. Jakarta: Grasindo, 1997

[2] C. Cooper, Tourism: Principles and practice. Pearson education, 2008.

[3] B. Weiler and C.M. Hall, Special interest tourism. Belhaven Press, 1992.

[4] Tourism Office of Kupang Regency, NTT, Data on the Number of Visits of Manikin Beach Tourists in 2014-2019, 2019.

[5] A.M. Firdaus, Research Method. Jelaja Nusa, 2012.

[6] I.K. Hariyana and I.G.A.O. Mahagangga, "Persepsi masyarakat terhadap pengembangan kawasan goa peteng sebagai daya tarik wisata di desa jimbaran kuta selatan kabupaten badung," Jurnal Destinasi Pariwisata, vol. 3, no. 1, pp. 24-34, 2015.

[7] J. Scheff and P. Kotler, "Crisis in the arts: The marketing response," California management review, vol. 39, no. 1, pp. 28, 1996

[8] H. Marpaung, Knowledge of Tourism. Bandung: Alfabeta, 2002

[9] H.N. Nasution and F.T. Mavondo, "Customer value in the hotel industry: What managers believe they deliver and what customer experience," International Journal of Hospitality Management, vol. 27, no. 2, pp. 204-213, 2008.

[10] Z. Nurhalimah, "Kemitraan Dalam Pengembangan Potensi Pariwisata (Studi Pada Dinas Kebudayaan dan Pariwisata Kabupaten Tulungagung)," Jurnal Ilmiah Administrasi Publik, vol. 6, no. 1, pp. 1-6, 2020.

[11] P. Plog, Sociological context, change in perception and motivation, 2005.

[12] R. Yanto, "Application of Analytical Hierarchy Process Methods in Efforts to Improve the Quality of Tourism Objects," Citec Journal, vol. 4, no. 3, 2017

[13] P. Kotler, J.T. Bowen, J. Makens and S. Baloglu, Marketing for hospitality and tourism, 2017.

[14] P. Kotler, J.T. Bowen and J.C. Makens, Marketing for Hospitality and Tourism (5th ed.). New Jersey: Pearson Education, 2010.

[15] A. Atkinson, "Answering the Eternal Question: What does the Customer want?" The Cornell Hotel and Restaurant Administration Quarterly, August, pp. 12-14, 1988.

[16] B. Knutson, "Frequent Travelers: Making them Happy and Bringing them Back," The Cornell Hotel and Restaurant Administration Quarterly, vol. 29, no. 1, pp. 83-87, 1988.

[17] H.F.M. Ruys and S. Wei, "Accommodation Needs of Mature Australian Travelers," Australian Journal of Hospitality Management, vol. 5, no. pp. 1, pp. 51-60, 1998

[18] F. Saleh and C. Ryan, "Analyzing Service Quality in the Hospitality Industry using the SERVQUAL Model," The Service Industries Journal, vol. 11 , no. 3, pp. 324-343, 1992.

[19] W. Poon and K.C. Low, "Are Travelers Satisfied with Malaysian Hotels?" International Journal of Contemporary Hospitality Management, vol. 17, no. 3, pp. 217-227, 2005. 